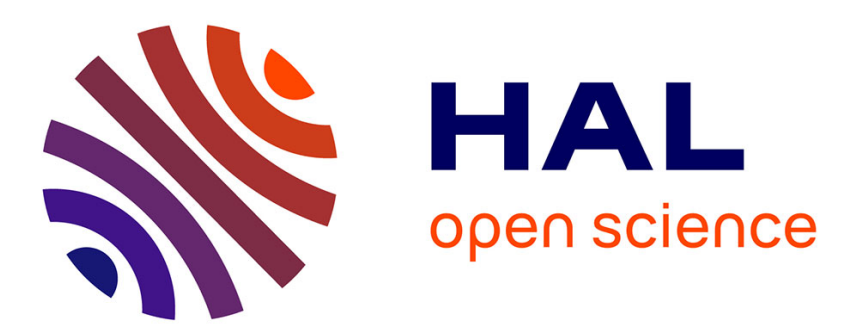

\title{
THE ENRICHMENT OF PHOSPHORUS NEAR Mo2 C PRECIPITATES IN STEEL
}

\author{
R. Möller, S. Brenner, H. Grabke
}

\section{To cite this version:}

R. Möller, S. Brenner, H. Grabke. THE ENRICHMENT OF PHOSPHORUS NEAR Mo2 C PRECIPITATES IN STEEL. Journal de Physique Colloques, 1986, 47 (C2), pp.C2-277-C2-280. 10.1051/jphyscol:1986241 . jpa-00225675

\section{HAL Id: jpa-00225675 https://hal.science/jpa-00225675}

Submitted on 1 Jan 1986

HAL is a multi-disciplinary open access archive for the deposit and dissemination of scientific research documents, whether they are published or not. The documents may come from teaching and research institutions in France or abroad, or from public or private research centers.
L'archive ouverte pluridisciplinaire HAL, est destinée au dépôt et à la diffusion de documents scientifiques de niveau recherche, publiés ou non, émanant des établissements d'enseignement et de recherche français ou étrangers, des laboratoires publics ou privés. 


\title{
THE ENRICHMENT OF PHOSPHORUS NEAR $\mathrm{MO}_{2} \mathrm{C}$ PRECIPITATES IN STEEL
}

\author{
R. MÖLLER, S.S. BRENNER ${ }^{+}$and H.J. GRABKE \\ Max-Planck Institut fur Eisenforschung, Düsseldorf, F.R.G. \\ +University of Pittsburgh, Pittsburgh, PA 15261, U.S.A.
}

Abstract - Atom probe analyses of $\mathrm{MO}_{2} \mathrm{C}$ precipitates in $\mathrm{Fe}-\mathrm{Mo}-\mathrm{C}-\mathrm{P}$ al loys have shown that the concentration of phosphorus is enhanced in the vicinity of molybdenum carbide particles and it is proposed that this trapping decreases the phosphorus concentration at grain boundaries leading to a decreased temper embrittleness.

\section{I - INTRODUCTION}

The beneficial effect of molybdenum on the temper embrittleness of steels is well known (1) but has not yet been satisfactorily explained. Since molybdenum has little effect on the amount of phosphorus segregated at grain boundaries in carbon-free iron alloys (2) it is cuite likely that molybdenum must be in the form of carbides to be able to scavenge the phosphorus.

To test this hypothesis we have used the FIM/atom probe to measure the concentration of phosphorus in molybdenum carbide and in the regions of the matrix surrounding the precipitates.

\section{II - FXPERIMENTAL}

An alloy containing $F e$, Mo, C, and $P$ was prepared by vacuum casting. Its composition is given in table 1. After forging: the material was cold drawn to $0.2 \mathrm{~mm}$ diameter. The wires were then sealed in quartz capsules and homogenized at $900^{\circ} \mathrm{C}$ for 16 hours. They were then given additional heat treatments at lower temperatures. Specimens for field-ion microscopy were prepared in the usual manner (3).

III - RESULTS

Carbide precipitates several $\mathrm{nm}$ in diameter as well as 1 arger ones ( $>30 \mathrm{~nm}$ ) were observed after annealing for $14 \mathrm{~h} \mathrm{~h}$ at $600^{\circ} \mathrm{C}$. Several carbide particles in close proximity to each other are shown in figure 1. The atom probe analysis of one of them (labeled "l"), shown in figure $2 \mathrm{a}$, gave a composition of $\mathrm{Mo}_{2} \mathrm{C}$. There was no indication of dissolved phosphorus in the carbide. The carbide thus differs from the nitride which dissolves as much as 5 ato phosphorus (4). The region between the carbides (1 abeled "2"), however, exhibited considerable phosphorus enrichment as indicated by the spectrum in figure $2 \mathrm{~b}$. The composition of the interface regions of these particles could not be measured but the analyses of other 
precipitates showed no strong adsorption of phosphorus directly at the carbide-matrix interface and confirmed that there is an appreciable enhancement of phosphorus in the matrix surrounding the particles. The distribution of the phosphorus in the carbide and matrix can be displayed most clearly in a plot of the seguence of arrival of the ions at the detector. Figure 3 shows such a plot of the data obtained from a $3 \mathrm{~nm}$ diameter carbide particle formed during $380 \mathrm{~h}$ annealing at $600^{\circ} \mathrm{C}$. The plot shows twenty atoms per line which was estinated to be approximately ecual to the number of atoms collected from each evaporated layer of $0.4 \mathrm{~A}^{\circ}$ thickness. No phosphorus atoms are observed in the carbide nor is there an appreciable enrichment of $P$ at the interface. Instead, there is an enhanced phosphorus concentration of about 2 at.o in a region approximately $15 \mathrm{~nm}$ wide surrounding the carbide.

\section{IT - DISCUSSION AND SUMMARY}

The atom probe results show that phosphorus is enriched in the vicinity of $\mathrm{MO}_{2} \mathrm{C}$ but not directly at the interface between the precipitate and the matrix. A Gibbsean type of equilibrium segregation due to a lowering of surface energies can therefore be ruled out. Since no phosphorus was found within the carbide the heterogeneous nucleation of the carbides at Mo-P clusters is also not likely. The enrichment is probably caused by dislocations formed during the nucleation and growth of the precipitates or by the presence of the elastic strain fields surrounding the precipitates, as discussed by Johnson and Voorhees(5). Long-range interactions of solutes with carbide precipitates similar to those observed in this study were reported previously by Piller, $\mathrm{Will}_{\mathrm{l}}$ er and Brenner for the Fe - TiC - Sb system (6). The effect of the phosphorus trapping on temper-embrittlement wil I be discussed elsewhere.

\section{REFERENCES}

1. Jin Yu and C.J.MCMahon, Jr., Met. Trans., l1A (1980) 277.

2. D.Y.Lee, E.V.Barrera, J.P.Stark, and H.L.Marcus, Met. Trans., 15A (1984) 1415 .

3. S.S.Brenner and M.K.Milier, J. Metals, 35 (1983) 54 .

4. S.S.Brenner and S.D.Walck, Proc. 27 th International Field Emission Symposium, Tokyo, Japan, eds. Y.Yashiroo and N.Igata, (Publisher Tokyo University, 1980).

5. W.C.Johns on and P.W.Voorhees, Met. Trans. 16A (1985) 337.

6. J.Piller, M.K.Miller and S.S.Brenner, Proc. 29 th International Field Emission Symposium, eds. H.O.Andren and H.Norden, (Publisher Almquist \& Wiksell Int., Stockholm, Sweden 1982) 473.

TABLE I. Composition of Alloy (at. $\frac{\circ}{\circ}$ )

$\begin{array}{cccccc} & \text { Mo } & \text { P } & \text { Mn } & \text { C } & \text { Fe } \\ \text { SM } 1706 & 0.548 & 0.105 & 0.042 & 0.34 & 98.966\end{array}$




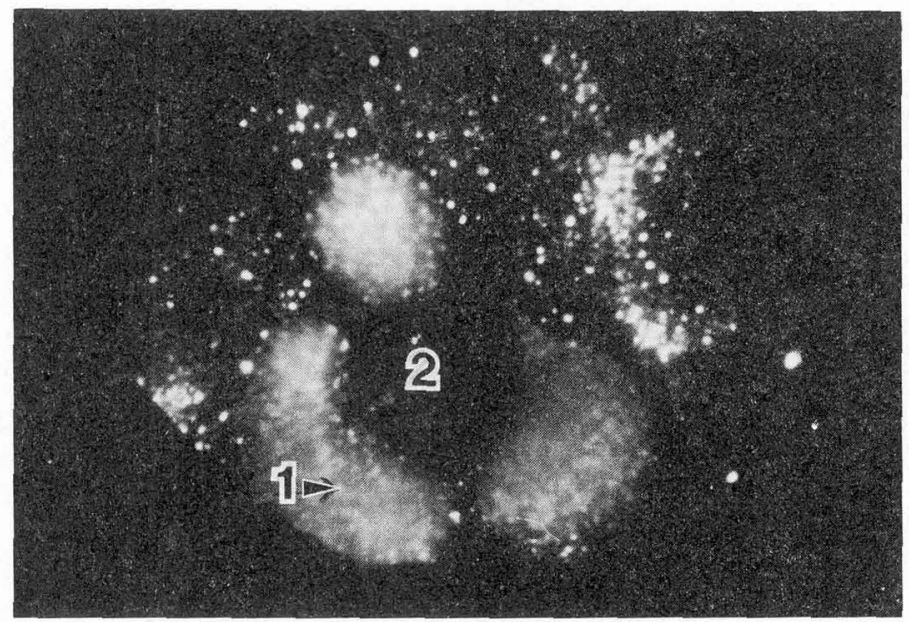

Figure 1. Carbide precipitate formed in a $110 y$ during $141 \mathrm{~h}$ at $600^{\circ} \mathrm{C}$.

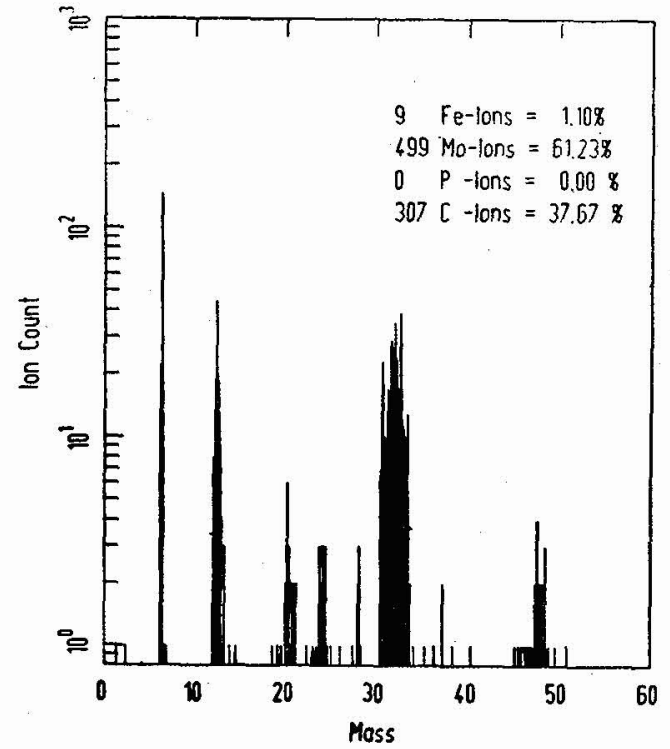

Figure 2a. Mass spectrum of carbide ("I" in figure 1.) showing absence of $P$.

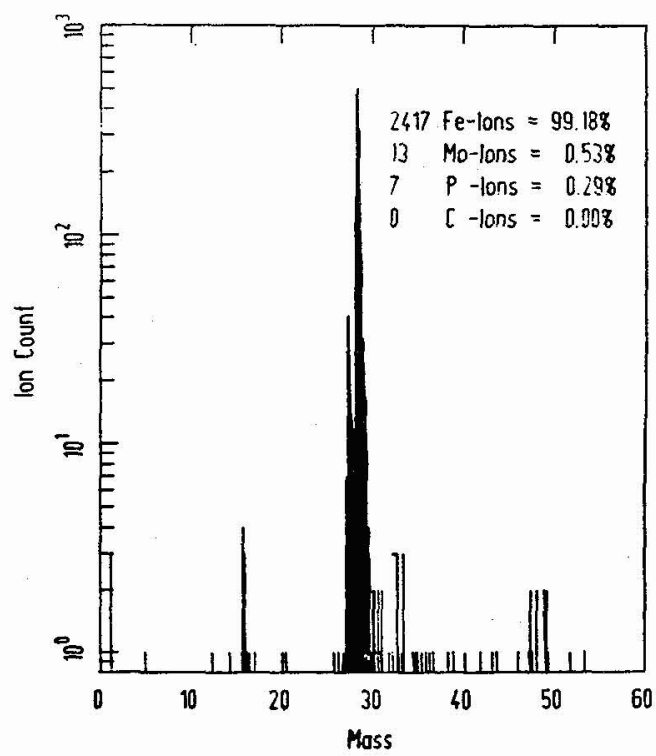

Figure 2b. Mass spectrum of region between carbides (" 2 " in figure 1) showing $P$ enrichment. 


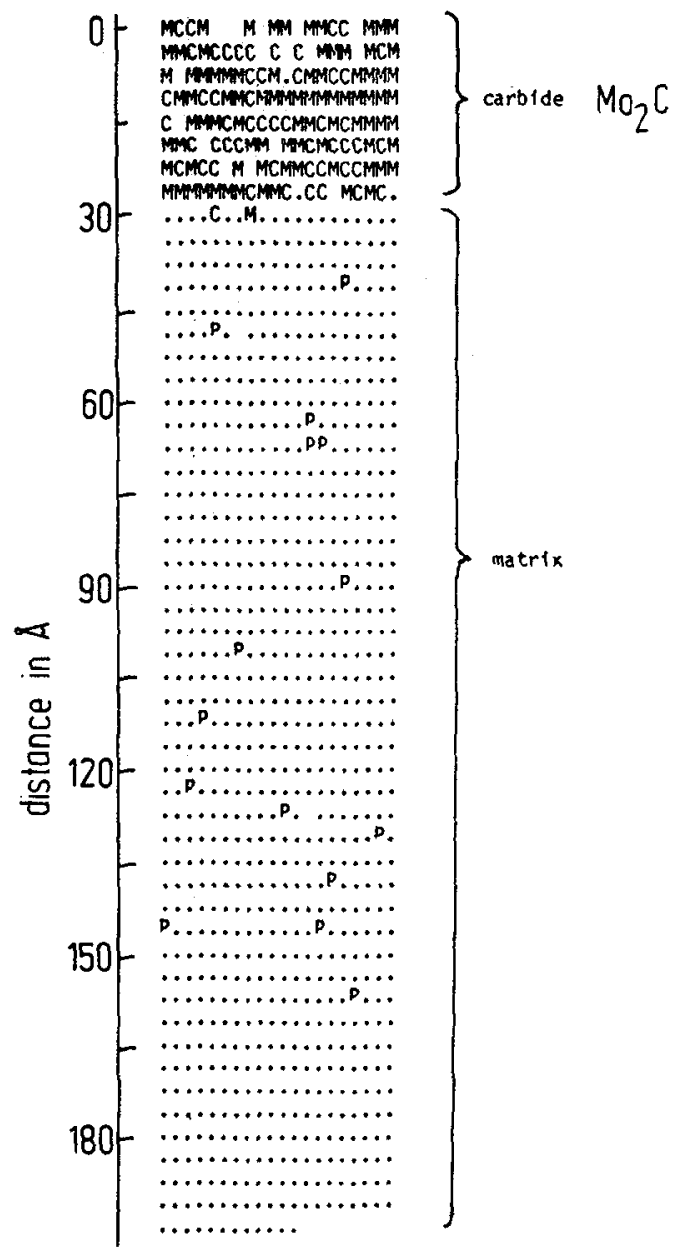

Figure 3. Field-evaporation seguence through carbide and region surrounding it. " $\mathrm{M} "=$ molybdenum, " $\mathrm{C} "=$ carbon, "." = iron, "P" = phosphorus. 